ks. Stanisław Wronka

\title{
Być błogosławieństwem dla świata - wspólne zadanie chrześcijan i żydów
}

Hasłem tegorocznego Dnia Judaizmu obchodzonego w Kościele Katolickim w Polsce już po raz siódmy jest zdanie z Za 8, 13: „Staniecie się błogosławieństwem"1. Cały werset 13 brzmi następująco ${ }^{2}$ :

„I tak jak byliście,

narodzie judzki i narodzie izraelski,

przekleństwem $\left(q^{e} l a \bar{l} \bar{a}(h)\right)^{3}$ wśród narodów,

tak [gdy] was wybawię (ǰs‘ w hifil),

będziecie błogosławieństwem ( $\left.b^{e} r \bar{a} \underline{k} \bar{a}(h)\right)$.

Nie lękajcie się, niech wasze ręce nabiorą siły!"

Te podnoszące na duchu słowa stanowią fragment rozdz. 8 Księgi Zachariasza, poświęconego w całości perspektywom zbawienia mesjańskiego ${ }^{4}$. Prorok głosił je w kilkanaście lat po zakończeniu niewoli babilońskiej (lata 520-518 przed Chr.), kiedy Izraelici zaczynali z trudem odbudowywać swoje

${ }^{1}$ Jest to poszerzony referat wygłoszony na spotkaniu międzyreligijnym w ramach VII Dnia Judaizmu w Kościele Katolickim w Polsce, które miało miejsce w Papieskiej Akademii Teologicznej w Krakowie 15 stycznia 2004 r.

${ }^{2}$ Wszystkie cytaty biblijne za: Biblia Tysiaclecia, Poznań ${ }^{5} 2002$.

3 Transliteracja według: S. WronkA, Transliteracja i transkrypcja alfabetu hebrajskiego, „Ruch Biblijny i Liturgiczny” 1 (2004), s. 45-58.

${ }^{4}$ Rozdziały 7-8 stanowią pewną całość, na którą składają się różne mowy. Zamykają one pierwszą część księgi (rozdziały 1-8), przypisywaną prorokowi Zachariaszowi (Proto-Zachariasz), która odcina się wyraźnie od rozdziałów 9-14 (Deutero-Zachariasz). Niektórzy egzegeci widzą jeszcze odrębną część w Za 12-14 (Trito-Zachariasz). Za 7 odnosi się do przeszłości, natomiast Za 8 wybiega w przyszłość i zawiera dziesięć obietnic, z których każda rozpoczyna się formułą: „Tak mówi Pan Zastępów” (w. 2.3. 4. 6. 7.9.14. 19. 20. 23). Powtarzają one tematy podjęte wcześniej i podkreślają zmianę losu Izraela przy pomocy czterech opozycji: konflikty / pokój (w. 10-12), przekleństwo / błogosławieństwo (w. 13), ściganie nieszczęściami / świadczenie dobra (w. 14-15), post / święto (w. 18-19); por. L. Alonso SchöKel, J. L. Sicre Diaz, I Profeti. Traduzione e commento (Commenti biblici), Roma ${ }^{3} 1996$, s. 1303-1307. 1340-1344; A. Cody, Księga Zachariasza, [w:] R. E. Brown, J. A. Fitzmyer, R. E. Murphy (red.), Katolicki komentarz biblijny (Prymasowska Seria Biblijna 17), Warszawa 2001, s. 872-874. 879. 
życie religijne i narodowe; świątynia jerozolimska nie była jeszcze całkiem ukończona, a mury Miasta Świętego leżały w gruzach ${ }^{5}$.

Zachariasz zapewniał, że jak Bóg ścigał Izraelitów nieszczęściami ( $\mathrm{ra}$ '), bo doprowadzili Go do gniewu ( $q s p$ w hifil), i nie żałował tego, tak teraz będzie świadczył im dobro (twb w hifil) (por. 8, 14-15). Pokonani przez wrogów i wypędzeni z własnej ojczyzny, byli przykładem przekleństwa, teraz staną się przykładem błogosławieństwa, gdy będą mogli spokojnie mieszkać w odbudowanym kraju i cieszyć się owocami własnej ziemi (por. 8, 4-5. 12)6.

Motywem takiej zmiany losu Izraela jest według proroka wielka „,zazdrość” (qin'ā $(h))$ i ,żarliwość” (hêma $(h))$ Boga o swój lud. Są to przejawy Jego miłości. Dlatego znów powróci na Syjon i zamieszka w Jerozolimie, tak że będzie nazwana „Miastem Wiernym” ('îr hä ě meț), a Syjon - „górą świętą" (har haqqṓdeš) (por. 8, 2-3). Wybawi swój lud i sprowadzi go do Jerozolimy ze wszystkich krańców ziemi (w czasie działalności Zachariasza tylko część przesiedleńców wróciła do Palestyny) i odnowi z nimi przymierze. Autor nie używa samego terminu ,przymierze” ( $\left.b^{e} r \hat{i} \underline{t}\right)$, ale przytacza formułę przymierza: „I będą moim ludem, a Ja będę ich Bogiem wiernym

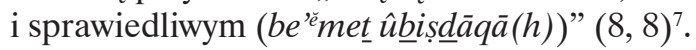

${ }^{5}$ Por. J. Homerski (oprac.), Ksiega Zachariasza. Wstęp-przekład-komentarz, [w:] Ksieggi proroków mniejszych: Nahuma, Habakuka, Sofoniasza, Aggeusza, Zachariasza, Malachiasza. Wstęp - przekład z oryginału - komentarz, t. II (Pismo Święte Starego Testamentu 12, 2), Poznań 1968, s. 249-251. 256-257.

${ }^{6}$ Zwroty „być przekleństwem”, „być błogosławieństwem”, w których orzecznikiem jest rzeczownik, a nie np. przymiotnik, są bardzo mocne. Oznaczają one taki stan, którego odpowiednio nikt albo każdy by sobie życzył; por. Rdz 22, 18: „Wszystkie ludy ziemi będą sobie życzyć szczęścia (brk w hitpael) [takiego, jakie jest udziałem] twego potomstwa". La Bibbia di Gerusalemme, Bologna ${ }^{8} 1988$, thumaczy: „foste oggetto di maledizione fra le genti” (byliście przedmiotem przekleństwa wśród ludów). Podobnie wyjaśniają ten zwrot L. Alonso SchöKel, J. L. Sicre DiAz, I Profeti, s. 1343-1344, chociaż inaczej oddają go w tłumaczeniu (s. 1340): „foste maledetti dai pagani, [...] sarete benedetti” (byliście przeklinani przez pogan, [...] będziecie błogosławieni). Błogosławieństwo jest darem Bożej hojności dotyczącym życia i płodności oraz wyrazem podziwu dla tej hojności ze strony człowieka, który błaga o taki dar, a gdy go otrzyma, dziękuje i wychwala Pana. Osoba pobłogosławiona przez Boga należy do Niego, objawia Jego dobroć w świecie, staje się punktem przyciągania i źródłem promieniowania dla innych; por. J. GuILlet, Błogostawieństwo, [w:] X. Léon-Dufour (red.), Stownik teologii biblijnej, Poznań-Warszawa ${ }^{2} 1982$, s. 79-81. Przekleństwo jest odwróconym echem błogosławieństwa, nigdy w tym świecie nie jest absolutne i nie niweczy do końca błogosławieństwa, rodzi się ostatecznie z oddalenia człowieka od Boga, źródła życia, przez grzech z inspiracji szatana; por. J. CoRbon, J. Guillet, Przekleństwo, [w:] X. Léon-Dufour (red.), Stownik teologii biblijnej, Poznań-Warszawa 21982, s. 803-806.

${ }^{7}$ Jest to nawiązanie do Jr 31, 31-33 (por. Ez 36, 23-28), gdzie mamy zapowiedź nowego przymierza. Zachariasz czerpie obficie z wcześniejszych proroków, zwłaszcza z Izajasza, Jeremiasza i Ezechiela, łącząc ich wątki w bogatą syntezę. 
Prorok przypomina o miłości, sprawiedliwości, a przede wszystkim o wierności i prawdomówności (‘ Bóg dotrzymuje raz danego słowa, nie przekreśla swego wyboru, nie zrywa przymierza, nie odbiera na zawsze swego błogosławieństwa. „Gniew Jego bowiem trwa tylko przez chwilę, a Jego łaskawość - przez całe życie" (Ps 30 [29], 6) ${ }^{8}$. Dlatego Zachariasz wzywa swych rodaków do odwagi, budzi w nich nadzieję na lepszą przyszłość, zachęca do wysiłku: „Nie lękajcie się, niech wasze ręce nabiorą siły!” $(8,13$; por. $8,9.15)$. Nawet jeśli przeżyli gehennę, odbudowa idzie bardzo opornie i trudno im zgodnie pracować (por. 8,10$)^{9}$, to mogą liczyć na swego Boga, dla którego wszystko jest możliwe (dosłownie: nic nie jest cudowne, niezwykłe - pl' w nifal; por. 8, 6). Nie ma więcej miejsca na smutek i posty, nastaje czas radości, wesela i przyjemnego święta (por. 8, 19).

Potrzebny jest jednak wysiłek moralny, trzeba zachować przykazania (dosłownie: „słowa” - de $\underline{b} \bar{a} r i ̂ m$ ), aby ta świetlana wizja mogła się urzeczywistnić. Nakazy dotyczą drugiego człowieka i są bardzo konkretne:

„Bądźcie prawdomówni ("meț) wobec bliźnich,

w bramach waszych ogłaszajcie wyroki sprawiedliwe ("̌met ûmišpāt), zapewniające zgodę (šălôm)!

Nie knujcie zła $(r \bar{a} ` \bar{a}(h))$ w sercu względem bliźnich,

nie przysięgajcie fałszywie (šéqer),

gdyż tego wszystkiego nienawidzę [...].

Ale miłujcie prawdę i pokój ("émet w wešălôm)!” $(8,16-17.19)^{10}$.

Znów na pierwsze miejsce wybija się tu, symetrycznie do postawy Boga, wierność i prawdomówność ('æmeț). Właśnie brak takich postaw, niesłuchanie napomnień dawnych proroków, za pośrednictwem których Bóg przekazywał słowo, Prawo przez swego Ducha, wywołał gniew Pana i doprowadził kwitnący i tętniący życiem kraj do ruiny, a Izraelitów rozproszył po wszystkich narodach (por. 7, 11-14). Autor nie wspomina nic o ludzkiej wrogości czy

\footnotetext{
${ }^{8}$ Psalm 30 [29] pochodzi najprawdopodobniej także z czasów bezpośrednio po niewoli babilońskiej; por. S. ŁACH, J. ŁACH (oprac.), Księga psalmów. Wstęp - przekład z oryginału - komentarz (Pismo Święte Starego Testamentu 7, 2), Poznań 1990, s. 200-202.

9 Trudności wewnętrzne po niewoli okazały się nie mniej dokuczliwe niż okupacja zewnętrzna; por. L. Alonso Schökel, J. L. Sicre Diaz, I Profeti, s. 1343-1344; J. Homerski, Księga Zachariasza, s. 363.

${ }^{10}$ Wcześniej Zachariasz przypominał napomnienia proroków sprzed niewoli babilońskiej: „Wydawajcie wyroki sprawiedliwe, okazujcie sobie wzajemnie miłość i miłosierdzie (hésed $w^{e-}$ rah̆̋̂̀m). Nie krzywdźcie wdowy ani sieroty, cudzoziemca ani biednego! Nie żywcie w sercach waszych złości względem bliźniego!" (7,9-10). Proto-Zachariasz bardzo akcentuje ludzkie działanie w ramach planu Bożego w przeciwieństwie do Deutero-Zachariasza, który każe pokładać ufność w samym działaniu Boga; por. L. Alonso SchöKel, J. L. Sicre Diaz, I Profeti, s. 1303.
} 
prześladowaniach Izraela ze strony obcych, lecz widzi główną i właściwie jedyną przyczynę upadku w grzechach ludu. Izraelici cierpieli z własnej winy, zostali ukarani przez Boga, który posłużył się obcymi mocarstwami ${ }^{11}$. Teraz jednak kara skończona - mówi prorok - Bóg błogosławi znów swojemu ludowi, trzeba tylko otworzyć uszy i serca na słowo Boga.

Gdy to uczynią, będą nie tylko sami zażywać błogosławieństwa, lecz staną się również błogosławieństwem dla innych: „I tak liczne ludy i mnogie narody przychodzić będą, aby szukać Pana Zastępów w Jeruzalem i zjednać sobie przychylność Pana [...] dziesięciu mężów ze wszystkich języków [...] uchwyci się skraju płaszcza Judejczyka, mówiąc: Chcemy iść z wami, albowiem zrozumieliśmy (dosłownie: ,usłyszeliśmy” - ̌̌m “w qal), że z wami jest Bóg” (8, 22-23), który darzy błogosławieństwem ${ }^{12}$.

Zachariasz nawiązuje do obietnicy Pana danej Abrahamowi w momencie jego powołania:

„Uczynię bowiem z ciebie wielki naród (gôj gādôl),

będę ci błogosławił (brk w piel) i twoje imię rozsławię:

staniesz się błogosławieństwem $\left(b^{e} r \bar{a} k \bar{a}(h)\right)$.

Będę błogosławił tym, którzy tobie błogosławić będą (brk w piel 2 razy), a tym, którzy tobie będą złorzeczyli (qll w piel), i Ja będę złorzeczył ('rr w qal).

Przez ciebie będą otrzymywały błogosławieństwo (brk w nifal)

ludy całej ziemi” (Rdz 12, 2-3).

Bóg potwierdził tę obietnicę, w nieco innych słowach, po próbie, jakiej poddał Abrahama, każąc mu złożyć swego umiłowanego syna Izaaka w ofierze (por. Rdz 22, 16-18). Cytowany tekst zapewnia, że Bóg będzie błogosławił Izraelowi i chronił go przed tymi, którzy zamierzaliby go przeklinać i prześladować. Natomiast wybrany lud nie ma być dla nikogo źródłem przekleństwa, nieszczęść, lecz przez niego błogosławieństwo Boże ma docierać do wszystkich ludzi ${ }^{13}$. Nie wyklucza to kary ze strony Boga, gdyby Izraelici sprzeniewierzyli się swemu powołaniu i przymierzu zawartemu z Bogiem. To do nich samych należy wybór pomiędzy błogosławieństwem i przekleństwem, życiem i śmiercią (por. Pwt 30, 15-20) ) $^{14}$.

${ }^{11} \mathrm{O}$ gniewie Bożym nad narodami uciskającymi Izraela i karze dla nich mówił prorok w swych wizjach (por. 1, 15; 2, 1-4. 12-13). Być może wzmianka w 8, 21-22 o ,zjednaniu sobie przychylności Pana" przez narody sugeruje, że jest On zagniewany na nich za ciemiężenie żydów; por. L. Alonso Schökel, J. L. Sicre Diaz, I Profeti, s. 1344.

${ }^{12}$ Znamienne w tych wyroczniach są uniwersalizm bez żadnych restrykcji i zupełny brak nacjonalizmu politycznego. „Narody nie składają hołdu żydom ani nie przynoszą im swoich bogactw. Jedyną rzeczą mającą znaczenie jest Pan”; L. Alonso SchöKel, J. L. Sicre Diaz, I Profeti, s. 1307.

${ }^{13}$ Por. J. Guillet, Błogosławieństwo, s. 82. 
Wielka katastrofa religijna i narodowa, jaką była niewola babilońska, nie przekreśliła zatem obietnicy danej Abrahamowi, nie oznaczała odrzucenia Izraela, odpadnięcia od łaski. Prorok Zachariasz potwierdził bowiem wybór Boży. Wiemy, że słowo prorockie w Biblii nie dotyczy tylko czasów, w których zostało wypowiedziane, ale jest otwarte daleko w przyszłość, często aż po kres dziejów ${ }^{15}$. Słowo Zachariasza pozostaje więc wciąż aktualne, tym bardziej że jest jednym z ostatnich słów prorockich w historii Izraela, bo niedługo potem prorocy znikną ze sceny. Możemy więc powiedzieć w świetle proroctwa Zachariasza, że i późniejsze nieszczęścia, które naród izraelski przeżywał, od dwóch nieudanych powstań przeciw Rzymowi w latach 66-73 i 132-135 aż po zagładę w czasie II wojny światowej, również nie przekreśliły Bożego błogosławieństwa. Spoczywa ono wciąż na Izraelu, „bo - jak powie św. Paweł - dary łaski i wezwanie Boże są nieodwołalne” (Rz 11, 29), i ma rozlewać się na wszystkich ludzi ${ }^{16}$.

Czytając pełne światła proroctwo Zachariasza, chrześcijanie czują się także spadkobiercami tego błogosławieństwa, widząc jego spełnienie w Jezusie, którego uznają za Mesjasza i Syna Bożego (por. Ga 3, 6-14) ${ }^{17}$. Nie chcą jednak odbierać żydom Bożego błogosławieństwa ani pozbawiać ich misji, którą mają do spełnienia w świecie. Uważają bowiem, że księgi Starego Testamentu pozostają wciąż słowem Bożym, które żydzi aktualizują zgodnie ze swą bogatą tradycją i charyzmatem. To słowo jest nam wspólne i w znacznej mierze wspólna jest wypływająca z niego nasza misja wobec zlaicyzowanego

${ }^{14}$ Pwt 29-30 powstały najprawdopodobniej również po niewoli babilońskiej; por. J. BLENKINsopp, Księga Powtórzonego Prawa, [w:] R. E. Brown, J. A. Fitzmyer, R. E. Murphy (red.), Katolicki komentarz biblijny (Prymasowska Seria Biblijna 17), Warszawa 2001, s. 171. „Dawne przymierze zawierało błogosławieństwa i przekleństwa (Pwt 27-28): jeśli z winy ludu przekleństwa się wypełniły, to błogosławieństwa wypełnią się z racji planu Bożego. Jednak wymagania przymierza ciągle obowiązują"; L. Alonso SchöKel, J. L. Sicre DiAz, I Profeti, s. 1341-1342.

${ }^{15}$ Po niewoli babilońskiej dwa główne problemy zajmowały żydów: odbudowa świątyni i restauracja eschatologiczna. Zachariasz kładł większy nacisk na tę drugą sprawę, podczas gdy współczesny mu Aggeusz akcentował bardziej pierwszą; por. L. AlONso SCHÖKEL, J. L. SicRE DiAZ, I Profeti, s. 1304. 1307.

${ }^{16}$ Por. Sobór Watykański II, Deklaracja o stosunku Kościoła do religii niechrześcijańskich Nostra aetate, nr 4; M. CzAJKowski, Czy substytucjonizm ma oparcie w Piśmie Świętym?, [w:] G. Witaszek, A. Paciorek, A. Kiejza (red.), Wszystko czynię dla Ewangelii. Księga pamiątkowa ku czci O. Prof. Hugolina Langkammera OFM, Lublin 2000, s. 73-80. W tekstach prorockich często ,z samego środka nawet klasycznego przekleństwa, wyłania się obraz albo przynajmniej stwierdzenie oznajmiające, że obietnica błogosławieństwa pozostaje nietknięta, że z tego spustoszenia zrodzi się życie"; J. GuILLET, Błogosławieństwo, s. 83; por. J. Corbon, J. Guillet, Przekleństwo, s. 805.

${ }^{17}$ Por. A. VAnhoye, La lettera ai Galati, Seconda parte, Roma 1985, s. 66-91; J. GuILlet, Btogostawieństwo, s. 84-85. 
i skorumpowanego świata: jest nią składanie świadectwa jedynemu Bogu i obrona wartości moralnych, stojących na straży godności człowieka ${ }^{18}$.

Wymowne są w tym względzie stwierdzenia Soboru Watykańskiego II, wyrażone w „Konstytucji dogmatycznej o Objawieniu Bożym Dei Verbum” (Rozdział IV O Starym Testamencie, nr 14-15): „Ta zaś ekonomia zbawienia, zapowiedziana, oznajmiona i wyjaśniona przez świętych autorów zawiera się w księgach Starego Testamentu jako prawdziwe słowo Boże. Z tego powodu owe księgi jako natchnione przez Boga na zawsze zachowują znaczenie: «To zaś, co niegdyś zostało napisane, napisane zostało także dla naszego pouczenia, abyśmy dzięki cierpliwości i pociesze, jaką niosą Pisma, podtrzymywali nadzieję» (Rz 15, 4). [...] Księgi zaś Starego Testamentu, na miarę położenia ludzkości przed dokonanym przez Chrystusa zbawieniem, dają wszystkim możliwość poznania Boga i człowieka, a także ukazują sposób, w jaki sprawiedliwy i miłosierny Bóg postępuje z ludźmi. Księgi te, choć zawierają także rzeczy niedoskonałe i przejściowe, ujawniają jednak prawdziwą Bożą pedagogię. Dlatego te właśnie księgi, które wyrażają żywe odczucie Boga, w których znajdują się wzniosłe pouczenia o Bogu, nadto zbawienna mądrość dotycząca ludzkiego życia oraz przedziwne skarby modlitw, w których wreszcie ukryta jest tajemnica naszego zbawienia, przez chrześcijan powinny być ze czcią przyjmowane"19.

W swoich ostatnich dokumentach Papieska Komisja Biblijna kontynuuje myśl soborową i zachęca egzegetów chrześcijańskich do zaznajomienia się z żydowskimi metodami interpretacyjnymi i korzystania z nich przy lekturze Biblii, zgodnie ze swoją optyką wiary, ufając, że z kolei żydzi skorzystają z badań egzegetycznych prowadzonych przez chrześcijan ${ }^{20}$.

${ }^{18}$ Por. J. Ratzinger, Wielość religii i jedno Przymierze, Poznań 2004, s. 11-37, 105-108.

${ }^{19}$ Konstytucje, dekrety, deklaracje. Tekst polski, Nowe tłumaczenie, Poznań 2002.

${ }^{20}$ Por. Naród żydowski i jego Święte Pisma w Biblii chrześcijańskiej, 2001, nr 22; Interpretacja Biblii $w$ Kościele, 1993, I. C. 2. W ostatnim czasie ukazało się sporo publikacji żydowskich dotyczących Biblii i judaizmu, zob. np.: S. PeCARIC (red.), Tora Pardes Lauder, Księga 1 Bereszit, Kraków 2001, Księga 2 Szemot, Kraków 2003, Hagada na Pesach i Pieśn nad Pieśniami, Kraków 2002 oraz Pieśni szabatowe i Błogosławieństwo po jedzeniu, Kraków 2002; 613 przykazań judaizmu oraz Siedem przykazań rabinicznych i Siedem przykazań dla nie-Żydów, Kraków 2000; A. CoHEN, Talmud. Syntetyczny wykład na temat Talmudu $i$ nauk rabinów dotyczacych religii, etyki i prawodawstwa, Warszawa 1995; S. DATNER, A. KAMIEŃSKA (wybór, przekład i opracowanie), Z mądrości Talmudu, Warszawa 1988; L. Ginzberg, Legendy żydowskie, Warszawa 1997; E. E. Dessler, Pożądaj prawdy, t. I-II, Kraków 2003; D. Lifschitz, Chcę błogostawić Pana... Psalm 34. Tradycja żydowska i chrześcijańska komentuje Psalmy, Kraków 1997; K. Gebert, 54 komentarze do Tory, Kraków 2003; P. ŚPIEWAK, Księga nad księgami. Midrasze, Kraków 2004; S. P. DE VRIES, Obrzędy i symbole Żydów, Kraków 1999. Dodać by tu trzeba ogromną literaturę dotyczącą Qumran i chasydów. 
Być błogosławieństwem dla współczesnego świata - to wielkie zadanie żydów i chrześcijan, ale będą mogli mu sprostać tylko wówczas, gdy staną się najpierw błogosławieństwem dla siebie nawzajem. Zachęcał do tego obydwie strony dialogu Jan Paweł II już w 1980 r. w Moguncji: „Żydzi i chrześcijanie, jako synowie Abrahama, są powołani do tego, by byli błogosławieństwem dla świata (por. Rdz 12, 2n), wspólnie przyczyniając się do pokoju i sprawiedliwości między wszystkimi ludźmi i narodami - i to w tej pełni i głębi, którą Bóg sam dla nas zamierzył, a także z gotowością do ofiar, których może wymagać tak wzniosły cel. Im bardziej nasze spotkanie będzie naznaczone tym świętym zobowiązaniem, tym bardziej będzie ono błogosławieństwem dla nas samych"21.

Papież kontynuował tę myśl w r. 1993 z okazji 50. rocznicy powstania w Getcie Warszawskim: „Oto wspólne zadanie, które nas czeka. Jest zatem konieczne, byśmy jako chrześcijanie i Żydzi stali się najpierw błogosławieństwem dla siebie nawzajem. Nastąpi to, jeżeli będziemy zjednoczeni w obliczu wielorakiego zła, które nadal nam zagraża: wobec obojętności i przesądów, a także wobec przejawów antysemityzmu"22.

Trzeba zatem, abyśmy umieli nawzajem przyznać: „zrozumieliśmy, że z wami jest Bóg”, i aby świat patrząc na nas mógł powiedzieć to samo: „Z wami jest Bóg” i przyłączyć się do nas. Oby ten kolejny dzień poświęcony dialogowi chrześcijańsko-żydowskiemu przyczynił się do tego choć w pewnej mierze!

Kraków

KS. STANISEAW WRONKA

${ }^{21}$ Przemówienie do przedstawicieli wspólnoty żydowskiej w Moguncji 17 XI 1980, [w:] W. Chrostowski, R. Rubinkiewicz (red.), Żydzi i judaizm w dokumentach Kościoła i nauczaniu Jana Pawta II (1965-1989), Warszawa 1990, s. 113.

${ }^{22}$ Telegram [...] do Komisji Koordynacyjnej Organizacji Żydowskich RP z okazji 50. rocznicy powstania w Getcie Warszawskim, „L'Osservatore Romano” wydanie polskie 14 (1993) nr 5-6, s. 59. Na temat stanowiska Ojca Świętego wobec żydów por. Ł. KAMYKowsKi, Nasi starsi bracia w wierze. Jana Pawła II program dialogu Kościoła z Żydami i judaizmem, [w:] Servo Veritatis. Materiały Międzynarodowej Konferencji dla uczczenia 25-lecia pontyfikatu Jego Świątobliwości Jana Pawła II, Uniwersytet Jagielloński 9-11 października 2003 r., Kraków 2003, s. 869-885. 


\section{Riassunto}

Essere una benedizione per il mondo - il compito comune dei cristiani e degli ebrei

Larticolo è una ampliata relazione, tenuta durante la VII Giornata del Giudaismo nella Chiesa Cattolica in Polonia, il cui motto suonava: „Diverrete una benedizione” (Za 8, 13). Il profeta Zacharia ricordava agli Israeliti dopo le traumatiche esperienze dell'esilio babilonese, che conformemente alla promessa data ad Abramo (cf. Gen 12, 2-3), Dio contuinava a portare loro la benedizione, che dovevano trasmettere a tutte le nazioni. Questa parola profetica rimane sempre attuale, anche dopo lo sterminio degli ebrei durante la seconda guerra mondiale, come ha ricordato il Concilio Vaticano II e che Giovanni Paolo II non cessa di sottolineare. Gli ebrei non sono stati rigettati, „perché i doni e la chiamata di Dio sono irrevocabili" ( $\mathrm{Rm} \mathrm{11,29),} \mathrm{ma} \mathrm{devono} \mathrm{essere} \mathrm{sempre} \mathrm{una} \mathrm{fonte} \mathrm{di} \mathrm{benedizione} \mathrm{per} \mathrm{il} \mathrm{mondo.}$ I cristiani si sentono anche eredi della benedizione di Abramo, che vedono compiuta in Gesù Cristo. Bisogna dunque, che le due comunità religiose diventino una benedizione per sé stesse e portino insieme il divino messaggio della pace e della giustizia al mondo contemporaneo, secolarizzato, diviso e corrotto. 